\title{
Effect of dual practice on service delivery time by surgeons in the Is- lamic Republic of Iran: multi-level analysis of a national survey, 2016
}

Mahboubeh Bayat, ${ }^{1,2}$ Azad Shokri, ${ }^{3}$ Roghayeh Khalilnezhad, ${ }^{4}$ Elmira Mirbahaeddin, ${ }^{5}$ Mahmoud Khodadost, ${ }^{6,7}$ Hamed Fattahi, ${ }^{8}$ Gholamhossein Salehi Zalani, ${ }^{2}$ Iraj Harirchi, ${ }^{9}$ Mehdi Yaser, ${ }^{10}$ Ebrahim Jaafaripooyan ${ }^{11}$ and Ali Akbari-Sari. ${ }^{11}$

${ }^{1}$ Gerash University of Medical Sciences, Gerash, Islamic Republic of Iran. ${ }^{2}$ Center for Health Human Resources Research \& Studies, Ministry of Health and Medical Education, Tehran, Islamic Republic of Iran. ${ }^{3}$ Social Determinants of Health Research Center, Kurdistan University of Medical Sciences, Sanandaj, Islamic Republic of Iran. ${ }^{4}$ Health Management and Economics Research Center, Iran University of Medical Sciences, Tehran, Islamic Republic of Iran. ${ }^{5}$ Telfer School of Management, University of Ottawa, Ontario, Canada. ${ }^{6}$ Department of Epidemiology, School of Public Health, Shahid Beheshti University of Medical Sciences, Tehran, Islamic Republic of Iran. ${ }^{7}$ Department of Epidemiology, School of Public Health, Iran University of Medical Sciences, Tehran, Islamic Republic of Iran. ${ }^{8}$ Department of Health Services Management, School of Health Management and Information Sciences, Iran University of Medical Sciences, Tehran, Islamic Republic of Iran. ${ }^{9}$ Department of Surgery, School of Medicine, Tehran University of Medical Sciences, Tehran, Islamic Republic of Iran. ${ }^{10}$ Department of Epidemiology, School of Public Health, Tehran University of Medical Sciences, Tehran, Islamic Republic of Iran. "Department of Health Management and Economics, School of Public Health, Tehran University of Medical Sciences, Tehran, Islamic Republic of Iran. (Correspondence to: Ali Ali Akbari-Sari: akbarisari@tums.ac.ir).

\begin{abstract}
Background: One of the work patterns which affects the supply of specialists is the phenomenon of dual practice (DP), i.e., working simultaneously in the public and private sectors. Uncontrolled DP in the surgery health workforce can have adverse effects on access to surgeons, efficiency, effectiveness and quality of surgery services.

Aims: The aim of this article is to examine the impact of DP on service delivery time by surgeons.

Methods: We used a prestructured form to collect data on surgery specialists in all 925 Iranian hospitals. National medical ID codes, council ID codes, first name, surname and father's name were used for data matching. Multilevel linear regression was used to assess the association between DP and study variables, which were recruitment type, faculty status, experience, sex and age.

Results: The 4642 surgery specialists in this study, representing 31.08\% of the total number of surgeons identified, spent mean 1.09 (standard deviation 0.33) hours full-time equivalent (FTE) on health care service delivery. Specialists with DP had long service delivery time $(\beta=0.427)$. Female specialists $(\beta=-0.049)$ and full-time specialists $(\beta=-0.082)$ spent less time on health care service delivery. Permanent specialists had higher FTE $(P<0.001)$ and as the population increases, FTE increases $(P<0.05)$.

Conclusions: Although DP had a direct impact on surgeons' working hours, it seems that a greater share of the difference in working time was used in the private sector services, leading to poor access to surgery services in the public sector. Therefore, it is necessary to develop a systems approach to regulate DP.
\end{abstract}

Keywords: surgeons, dual practice, health care service delivery, Iran

Citation: Bayat M; Shokri A; Khalilnezhad R; Mirbahaeddin E; Khodadost M; Fattahi H; et al. Effect of dual practice on service delivery time by surgeons in Islamic Republic of Iran: multi-level analysis of a national survey, 2016. East Mediterr Health J. 2018;24(9):866-876. https://doi. $\operatorname{org} / 10.26719 / 2018.24 \cdot 9.866$

Received: 25/09/17; accepted: 28/03/18

Copyright @ World Health Organization (WHO) 2018. Some rights reserved. This work is available under the CC BY-NC-SA 3.0 IGO license (https:// creativecommons.org/licenses/by-nc-sa/3.o/igo).

\section{Introduction}

Surgical care is one of fundamental services in a health system; it has a key role in medical services delivery for a wide range of diseases, from prevention to acute treatments for emergency and cancer (1). This type of care relates to $30 \%$ of the burden of the burden of medical services delivery for a wide range of diseases (2) and accounts for more than $1.25 \%$ of the world's gross domestic product (2015-2030) (3). However, according to a 2015 estimation, at least 4.8 billion of the world's population do not have access to surgery services, and most of this inaccessibility occurs in low- to middle-income countries (4). The current shortage of surgery specialists will be exacerbated in the near future due to changes in world demography in aging and noncommunicable diseases, the prevalence of chronic disease and workforce flow, especially in mid- dle- to high-income countries $(5,6)$. One of the workforce flows which affects specialist supply is the phenomenon of dual practice (DP), defined as working simultaneously in the public and the private sector $(7,8)$. This situation is common among specialists, especially surgeons, whose performance and job may be more associated with the private sector (9); however, the phenomenon is not restricted to a specific region. it is witnessed in most countries worldwide ranging from Europe to low/middle income countries such as Egypt, Indonesia and Vietnam (10). Uncontrolled DP in the surgery health workforce can have adverse effects on adequate access to surgeons, efficiency, effectiveness and quality of services. Since total annual working hours show the average labour supply across the year, engagement in DP may increase the total labour supply by increasing total working time, though 
it mostly leads to an increase in the private supply and consequent reduction in the public supply due to the decreased time spent in this sector $(8,11,12)$.

Full-time equivalent (FTE), a unit which indicates workload of physicians through calculation of working hours, can indicate increasing or decreasing impact of DP on the supply (9). This is why developed countries use FTE, or amount of time allocated to each service delivery location by the specialist, to estimate supply (13-15).

Despite the fact that DP among surgeons and their conduct in the allocation of working hours to the public and private sectors significantly helps health workforce planning in the provision of required surgery services, there is a lack of comprehensive studies in this respect. Hence, the present study aimed to examine the effect of DP on service delivery time by surgeons in the Islamic Republic of Iran as a developing country

\section{Methods}

\section{Survey}

A national survey was carried out in 2016 using a multi-method approach to identify and analyse the current status of DP among surgery specialist physicians. A prestructured form, together with guidelines on completing, it was developed to collect data on specialists working in public and private hospitals in the Islamic Republic of Iran. We covered all 925 hospitals in the country; public hospitals were either owned by the Ministry of Health and Medical Education or by other public sector organizations such as the social security organization, the Ministry of Petroleum and the armed forces. Private sector hospitals included both private and charity hospitals. Supervision and accreditation for all governmental, nongovernmental and private hospitals in the provinces is by the medical sciences universities, and they were the data collection reference for this study.

\section{Data collection}

In this study, a tool was developed to collect data from all hospitals of the country. Access and Excel software were utilized for data management; STATA, version 12, and $R$ (3.0.1) software were used for data analysis. The tool comprised 2 parts: a data collection form together with instructions for completing tables on demographic characteristics, recruitment and occupation status, specifications of the employing hospitals and affiliating organization and time share. This includes information regarding number of active months per annum, average number of active days per month and average number of active hours per day. Surgery specialists were enrolled in this study; anaesthesiologists are members of the surgical specialty in the Islamic Republic of Iran and have an important role in the surgical team, so they were included in the study. They are also included among the surgical specialties in some other regions, e.g. Scandinavia (16).

In the instructions, necessary explanations regarding answering questions with specialized knowledge were provided to promote accurate answers. After developing the form by reviewing studies on DP and FTE, it was finalized using administrative and academic experts familiar with DP in the Islamic Republic of Iran. Face validity and content validity of each section was approved by applying the views of experts. We sent the data collection forms and instructions to all universities; we sent reminders and monitored the process for completing the forms every 15 days. Finally, the hospitals were directly contacted to increase the response rate after 2-3 months.

\section{Quality control}

To increase accuracy in the study results and minimize errors in data entry by various users and taking into consideration the necessity of cleaning the collected data, a recognized method in the data engineering field, extraction, transformation and loading, was used. This method was adjusted and adapted to match data from the reference banks through data recapturing (17) and has been described previously (18).

With the aim of matching the acquired data from the survey with the available reference data banks, 3 criteria for each data item, including medical council code, national ID number, name, surname and name of father (together with initials), were used as matching variables to identify the recaptured data for the same person. This was performed by using the SQL functions of Access.

\section{Identifying of physicians with dual practice}

To identify the physicians holding multiple jobs, a data matching model was applied: duplicate data were detected among the health ministry databases and other public and private records. After identifying duplicate data (indicating physicians with DP), the main occupation location was specified based on type of recruitment relation listed on the forms. The share of dual practice among public sector specialists in each province and its relation with other characteristics of the physicians and conditions of provinces was then determined.

In this study, response rate was $93 \%$ (858 of the 925 hospitals). Out of 14931 surgery specialists, a total of 4642 surgery specialists were enrolled in this study.

\section{Statistical analysis}

Descriptive statistics in terms of mean, standard deviation (SD), frequency and percentage were used. Average time share was calculated for each specialty using the following formula (19).

$$
\mathrm{\Gamma E}=\frac{\sum_{i=1}^{\infty}\left(\frac{M_{i} \times D_{i} \times H_{i}}{W_{i} \times 40 \mathrm{~h}}\right)}{N}
$$

\section{Where:}

$M=$ number of individual active months a year

$\mathrm{D}=$ mean individual active days per $\mathrm{M}$

$\mathrm{H}=$ mean individual hours per $\mathrm{D}$ 
$\mathrm{W}=$ number of weeks per year

$\mathrm{N}=$ number of specialties.

Available annual working hours $=\mathrm{W}(\mathrm{i}) \times 40$ (routine working hours a week in the Islamic Republic of Iran)

Independent samples t-test and 1-way analysis of variance were used to compare mean FTE between study subgroups. Multilevel linear regression analysis was used to examine the relationship of the variables with DP. To measure the correlation of the findings in each province, these analyses were conducted via multilevel models in which the coefficients allowed change in each province (or even towns if necessary). To identify the number of required levels (efficiency), the likelihood ratio test was used. Finally, we used the backward elimination method to remove inefficient variables from the model in order to obtain the most parsimonious model (20). P-value $<0.05$ was considered significant.

\section{Ethical approval}

The ethical committee of Tehran University of Medical Sciences assessed and approved the study methodology and ethical considerations (ethical code IR.TUMS.VCR. REC.1395.1045 dated 16 November 2016).

\section{Results}

\section{Descriptive statistics}

The number of surgery specialists included in this study was 4642; 3048 (65.7) were male, and the main age group was 45-55 years, 1911 (41.2\%) (Table 1). The majority were employed in teaching hospitals of medical universities, 3854 (83.0\%). In terms of recruitment type 1414 (30.5\%) were employed on a contractual basis. The largest groups of specialists worked in obstetrics and gynaecology 1049 $(22.6 \%)$, general surgery $885(19.1 \%)$ and anaesthesiology $772(16.6 \%)$. We found that $2929(63.1 \%)$ were engaged in DP, i.e. they were working in other service locations as well.

\section{Full-time equivalent status}

Specialists' time share showed that on the whole specialists spent an average 1.09 (SD 0.33) FTE on health care service delivery. In comparison to other specialists, those working in nose, throat, head and neck surgery, general surgery and neurosurgery spent more time on service delivery, mean 1.28 (SD 0.33) FTE hours (Table 2).

Moreover, specialists who engaged in DP spent significantly more FTE, on average 1.26 (SD 0.30), compared to the others. Information on the FTE of specialists' characteristics is shown in Table 3.

\section{Impact of dual practice on surgeons' full-time equivalent}

In multilevel linear regression analysis, surgeons engaged in DP had a significantly higher FTE $(\beta=0.12, P$ $\leq 0.001)$. The greatest differences for FTE between dual

\begin{tabular}{|c|c|c|}
\hline Characteristic & No. & $\%$ \\
\hline \multicolumn{3}{|l|}{ Sex } \\
\hline Male & 3048 & 65.7 \\
\hline Female & 1594 & 34.3 \\
\hline \multicolumn{3}{|l|}{ Age (years) } \\
\hline$<40$ & 1096 & 23.6 \\
\hline $40-45$ & 683 & 14.7 \\
\hline $45-55$ & 1911 & 41.2 \\
\hline $55-65$ & 706 & 15.2 \\
\hline$>65$ & 246 & 5.3 \\
\hline \multicolumn{3}{|l|}{ Main occupation location } \\
\hline University hospital & 3854 & 83.0 \\
\hline Social security hospital & 211 & 4.5 \\
\hline Army forces hospital & 36 & 0.8 \\
\hline Petrochemical company hospital & 24 & 0.5 \\
\hline Other public hospital & 517 & 11.1 \\
\hline \multicolumn{3}{|l|}{ Faculty membership status } \\
\hline Member & 1154 & 24.9 \\
\hline Non-member & 3488 & 75.1 \\
\hline \multicolumn{3}{|l|}{ Employment status } \\
\hline Geographic full-time & 1194 & 25.7 \\
\hline Non-full-time & 3448 & 74.3 \\
\hline \multicolumn{3}{|l|}{ Recruitment type } \\
\hline Permanent & 1395 & 30.1 \\
\hline Zarib Ka & 845 & 18.2 \\
\hline Payam avar ${ }^{\mathrm{b}}$ & 5 & 0.1 \\
\hline Peymanic $^{c}$ & 418 & 9.0 \\
\hline Contractual & 1414 & 30.5 \\
\hline Other & 348 & 7.5 \\
\hline Unspecified & 217 & 4.7 \\
\hline \multicolumn{3}{|l|}{ Surgical specialism } \\
\hline General surgery & 885 & 19.1 \\
\hline Orthopaedics & 535 & 11.5 \\
\hline Urinary tract \& genital & 347 & 7.5 \\
\hline Neurosurgery & 224 & 4.8 \\
\hline Nose, throat, head \& neck & 390 & 8.4 \\
\hline Obstetrics \& gynaecology & 1049 & 22.6 \\
\hline Ophthalmology & 440 & 9.5 \\
\hline Anaesthesiology & 772 & 16.6 \\
\hline \multicolumn{3}{|l|}{ Dual practice } \\
\hline Yes & 2929 & 63.1 \\
\hline No & 1713 & 36.9 \\
\hline
\end{tabular}

${ }^{a}$ A recruitment contract in which medical specialty graduates who are legally committed to certain obligations fulfil these obligations in a health-related centre. ${ }^{b} \mathrm{~A}$ recruitment contract in which graduates who are committed to do obligatory military service work in health related centres instead, mostly in deprived areas. 'Semi-permanent. 
Table 2 Status of full-time equivalent (FTE) distributed by characteristics of specialists

\begin{tabular}{|c|c|c|c|}
\hline Characteristic & FTE & SD & P-value \\
\hline \multicolumn{4}{|l|}{ Sex } \\
\hline Male & 1.11 & 0.35 & \multirow[t]{2}{*}{0.001} \\
\hline Female & 1.05 & 0.29 & \\
\hline \multicolumn{4}{|l|}{ Age (years) } \\
\hline$<40$ & 1.04 & 0.29 & \multirow[t]{5}{*}{0.005} \\
\hline $40-45$ & 1.05 & 0.34 & \\
\hline $45-55$ & 1.10 & 0.34 & \\
\hline $55-65$ & 1.20 & 0.33 & \\
\hline$>65$ & 1.10 & 0.32 & \\
\hline \multicolumn{4}{|l|}{ Main occupation location } \\
\hline University hospital & 1.10 & 0.33 & \multirow[t]{2}{*}{0.001} \\
\hline Other hospital & 1.07 & 0.32 & \\
\hline \multicolumn{4}{|l|}{ Faculty membership status } \\
\hline Member & 1.23 & 31.00 & \multirow[t]{2}{*}{0.52} \\
\hline Non-member & 1.05 & 32.00 & \\
\hline \multicolumn{4}{|l|}{ Employment status } \\
\hline Geographic full-time ${ }^{\mathrm{a}}$ & 1.12 & 0.34 & \multirow[t]{2}{*}{0.001} \\
\hline Non-full-time & 1.01 & 0.28 & \\
\hline \multicolumn{4}{|l|}{ Recruitment type } \\
\hline Permanent & 1.17 & 0.33 & \multirow[t]{6}{*}{0.001} \\
\hline Zarib $\mathrm{K}^{\mathrm{b}}$ & 1.04 & 0.27 & \\
\hline Payam avar ${ }^{c}$ & 1.08 & 0.32 & \\
\hline Peymani $^{\mathrm{d}}$ & 1.12 & 0.32 & \\
\hline Contractual & 1.07 & 0.34 & \\
\hline Other & 1.02 & 0.34 & \\
\hline \multicolumn{4}{|l|}{ Surgical specialism } \\
\hline General surgery & 1.16 & 0.35 & \multirow[t]{8}{*}{0.04} \\
\hline Orthopaedics & 1.11 & 0.34 & \\
\hline Urinary tract \& genital & 1.18 & 0.37 & \\
\hline Neurosurgery & 1.28 & 0.33 & \\
\hline Nose, throat, head \& neck & 1.12 & 0.34 & \\
\hline Obstetrics \& gynaecology & 1.07 & 0.30 & \\
\hline Ophthalmology & 1.06 & 0.29 & \\
\hline Anaesthesiology & 0.93 & 0.27 & \\
\hline \multicolumn{4}{|l|}{ Dual practice } \\
\hline Yes & 1.26 & 0.30 & \multirow[t]{2}{*}{0.005} \\
\hline No & 0.81 & 0.12 & \\
\hline
\end{tabular}

$S D=$ standard deviation.

${ }^{a}$ Physicians who are supposed to be full time (54 h per week) and are not allowed to be active in any other locations/sectors except their main occupation.

${ }^{b}$ A recruitment contract in which medical specialty graduates who are legally committed to certain obligations fulfil these obligations in a health-related centre.

'A recruitment contract in which graduates who are committed to do obligatory military service work in health-related centres instead, mostly in deprived areas. ${ }^{\mathrm{d}}$ Semipermanent.

practitioners and non-dual practitioners were observed among specialists of nose and throat and head and neck surgery $(\beta=0.49, P \leq 0.001$, general surgery $(\beta=0.48, P \leq$ $0.001)$ and neurosurgery $(\beta=0.48, P \leq 0.001)$.
Female compared to male specialists $(\beta=-0.49, P \leq$ $0.001)$ and full time compared to non-full-time specialists ( $\beta=-0.082, P \leq 0.001)$ spent less time on health care service delivery (Table 3 ). In terms of recruitment type and provincial characteristics, the specialists with permanent recruitment type had higher FTE $(P \leq 0.001)$ and as the population increases, FTE increases $(P<0.05)$.

Table 4 shows the comparison of FTE between DP and non-DP and factors of affecting FTE for the two groups. Among the non-DP practitioners, those younger than 39 years $(P=0.005)$, Zarib $K(P=0.004)$ and geographic full-time surgeons $(P=0.005)$ and female surgeons $(\beta$ $=0.021, P \leq 0.001$ ) had higher FTE compared with their peers (Zarib $\mathrm{K}$ is a recruitment contract in which medical specialty graduates who are legally committed to certain obligations fulfil these obligations in a health-related centre).

Moreover, despite the general results, among nonDP surgeons, obstetrics and gynaecology was one of the specialties which demonstrated the highest FTE. There was a negative association between the proportion of private hospitals in each province and FTE, and there was a positive association between regional development and FTE (Table 4).

\section{Discussion}

Our findings on 4642 surgery specialists showed that they worked 43.6 hours per week on average (1.09 FTE). Comparison of different fields showed that DP had more impact on FTE and total working hours in certain specialty areas, including nose, throat, head and neck surgery, general surgery and neurosurgery. Studies showed that these specialties were the highest paying fields in the private sector (9). In comparison, in Australia working hours per week were 50 hours (1.25 FTE) for neurosurgeons, 49.5 hours (1.23 FTE) for urologists and 47.5 hours (1.19 FTE) for general surgeons (21). In the United States of America (USA), maximum hours of service per week for surgeons in orthopaedics, internal medicine and neurosurgery are 1.6, 1.4 and 1.4 FTEs, respectively (22). Therefore, it seems that increased demand for the services of such specialists and the trend in burden of disease, especially in low-income countries (23), together with global population aging has led to longer waiting lists for these services (24) and more time being spent in responding to these needs.

Previous research has shown DP has no significant effects on the total working hours in the public sector. In fact, most of the physicians who work in DP complete their hours in a public hospital and work extra hours in a private hospital (25). Another study showed that, for some surgical specialties, practitioners spend fewer hours a week in the public sector to accommodate their other work (DP) in the private sector (9). One study showed that financial and non-financial attraction in the private sector caused DP specialists who do not have time constraints to spend more time working in this sector (26).

Another study indicated that some surgeons, e.g. otolaryngology and ophthalmology surgeons, spend 
Table 3 Multi-level linear regression analysis to assess association between study variables and full-time equivalent hours

\begin{tabular}{|c|c|c|c|c|c|}
\hline \multirow[t]{2}{*}{ Characteristic } & \multirow[t]{2}{*}{$\boldsymbol{\beta}$} & \multicolumn{2}{|c|}{$95 \% \mathrm{CI}$} & \multirow[t]{2}{*}{ P-level } & \multirow[t]{2}{*}{ P-variable } \\
\hline & & Lower limit & Upper limit & & \\
\hline \multicolumn{6}{|c|}{ With dual practice } \\
\hline \multicolumn{6}{|l|}{ Surgical specialization } \\
\hline \multicolumn{6}{|c|}{ (Without dual practice) } \\
\hline General surgery & 0.48 & 0.52 & 0.45 & 0.001 & \\
\hline Orthopaedics & 0.44 & 0.49 & 0.38 & 0.001 & \\
\hline Urology & 0.46 & 0.53 & 0.39 & 0.001 & \\
\hline Neurosurgery & 0.48 & 0.60 & 0.36 & 0.001 & \\
\hline Nose, throat, head \& neck & 0.49 & 0.54 & 0.43 & 0.001 & 0.001 \\
\hline Obstetrics \& gynaecology & 0.40 & 0.43 & 0.37 & 0.001 & \\
\hline Ophthalmology & 0.39 & 0.43 & 0.35 & 0.001 & \\
\hline Anaesthesiology & 0.32 & 0.36 & 0.29 & 0.001 & \\
\hline Total & 0.427 & 0.442 & 0.412 & 0.001 & \\
\hline
\end{tabular}

Physicians' characteristics

Sex

Male

Female

Age (years)

$<39$

39-45

45-55

55-65

$>65$

Experience (years)

$$
\begin{aligned}
& \leq 5 \\
& 6-15 \\
& 15-25 \\
& >25
\end{aligned}
$$

\section{Recruitment type}

Permanent

$$
\text { Zarib Ka }
$$

Payam avar ${ }^{\mathrm{b}}$

Peymanic

Contractual

$$
\text { Other }
$$

$-0.049$

$-0.067$

$-0.030$

0.001

0.001

$\begin{array}{llll}0.01 & -0.019 & 0.041 & 0.484 \\ 0.03 & 0.010 & 0.059 & 0.006 \\ 0.12 & 0.092 & 0.155 & 0.001 \\ 0.04 & 0.000 & 0.089 & 0.051\end{array}$

\section{Faculty status}

Non-faculty

Faculty

\section{Full-time status}

Not full-time

Geographic full-timed

$-0.082$

0.009
0.134
0.098

-0.020
0.101
0.054

0.039

0.529

0.167

0.001

0.142

0.001

0.001

$\begin{array}{lccc}-0.086 & -0.115 & -0.056 & 0.001 \\ -0.135 & -0.405 & 0.135 & 0.328 \\ -0.040 & -0.074 & -0.006 & 0.022 \\ -0.084 & -0.108 & -0.061 & 0.001 \\ -0.102 & -0.139 & -0.065 & 0.001\end{array}$

Provincial characteristics

\section{Population (000)}

$$
\leq 500
$$

$$
\text { 501-2000 }
$$

2001-5000

$$
\geq 5001
$$

Extent of regional development ${ }^{e}$

Share of private hospitals $f$

$\begin{array}{cc}0.075 & 0.013 \\ 0.051 & -0.111 \\ 0.197 & 0.005 \\ 0.003 & -0.032 \\ -0.073 & -0.375\end{array}$

$\begin{array}{ll}0.136 & 0.017 \\ 0.214 & 0.536 \\ 0.389 & 0.044 \\ 0.031 & 0.992 \\ 0.229 & 0.635\end{array}$

0.031

0.992

0.635

${ }^{a}$ A recruitment contract in which medical specialty graduates who are legally committed to certain obligations fulfil these obligations in a health-related centre. ${ }^{b} A$ recruitment contract in which graduates who are committed to do obligatory military service work in health-related centres instead, mostly in deprived areas. 'Semi-permanent. ${ }^{d P h y s i c i a n s ~ w h o ~ a r e ~ s u p p o s e d ~ t o ~ b e ~ f u l l ~ t i m e . ~}$ (54 hours per week) and are not allowed to be active in any other locations/sectors except their main occupation. EEstimated according to development coefficient in each province. Estimated according to proportion of private hospitals in each province. 


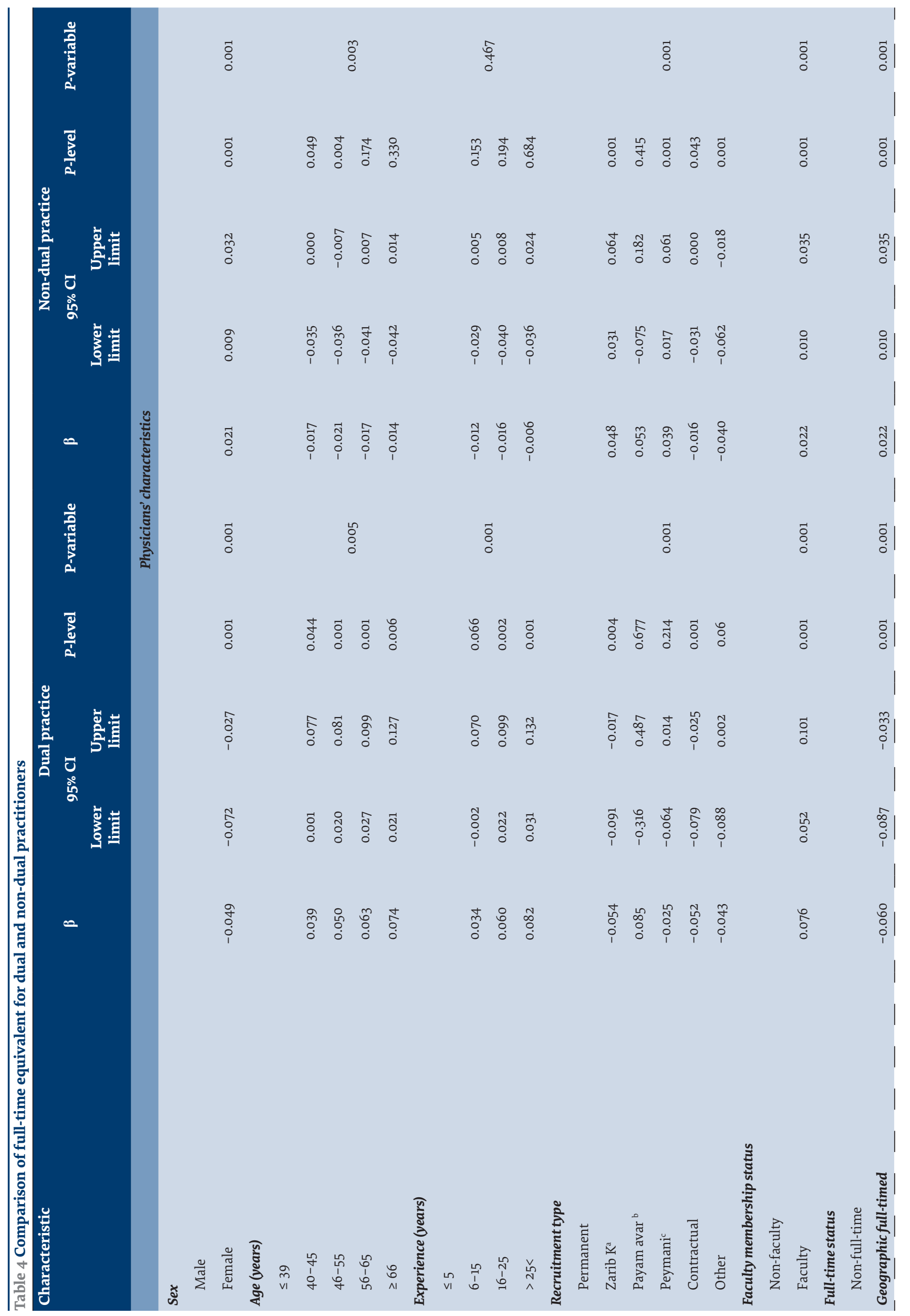




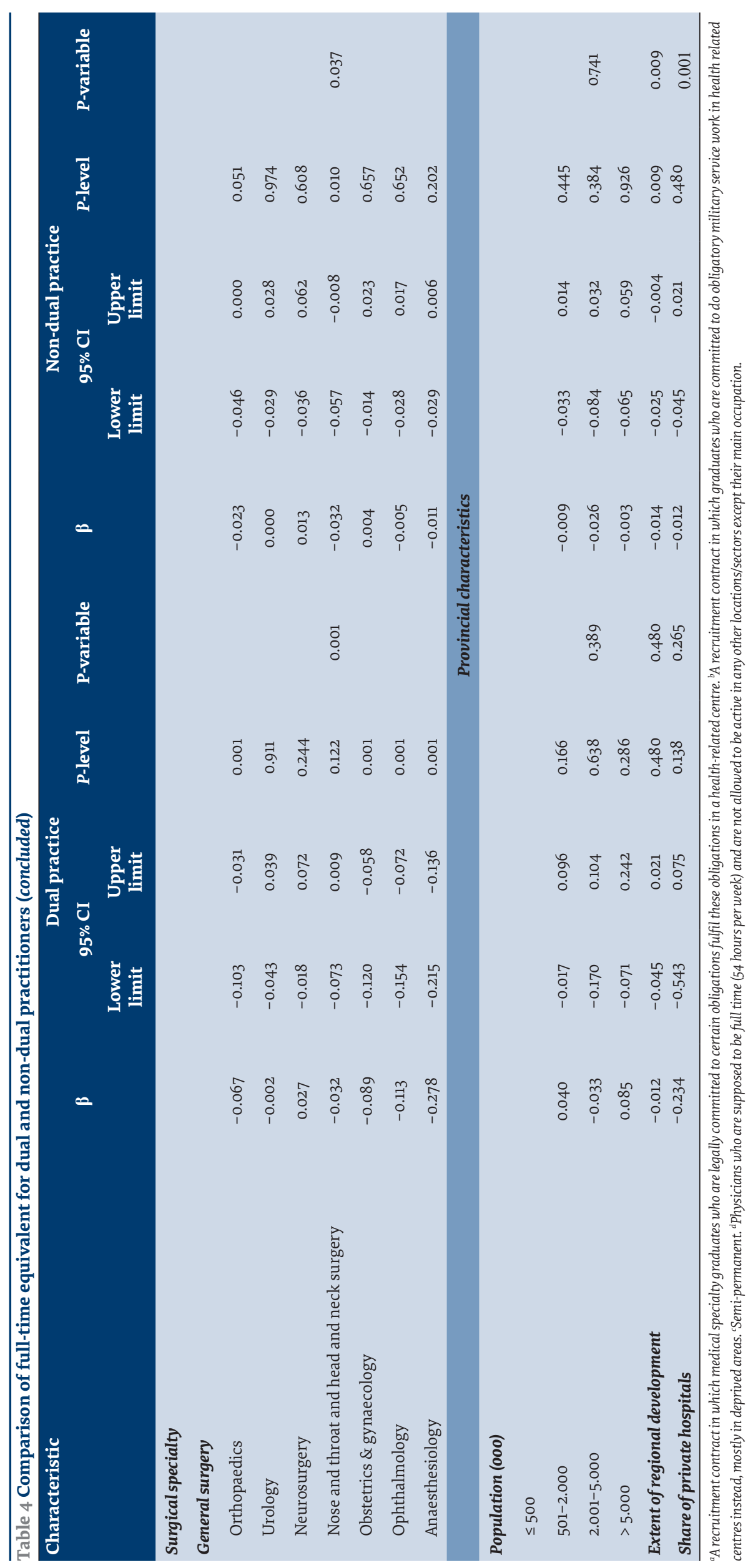


more time in DP owing to their having the highest pay in the private sector compared with the other specialties (9). Therefore, it seems that the private sector has increased its share in the surgery market because of the higher income (27). Another incentive that encourages specialists' efforts to transfer from public to private practice is the differences in the remuneration mechanism: dual practitioners may be more motivated to dedicate their time to private practice when they are paid fixed salary in the public sector versus fee-for-service or an hourly rate paid in the private sector $(25,26)$.

In terms of non-financial factors, one of the most important reasons for the doctors' tendency to engage $\mathrm{DP}$ is the different work context in the 2 sectors. For instance, having more autonomy in private hospitals was considered valuable by specialists. Other non-financial factors such as relationships between different health providers, professional satisfaction, public responsibility, prestige, etc. were generally perceived as much better in the private sector (28). On the other hand, low salaries, poor infrastructure, unmanageable workloads, staff shortages and absenteeism lead to low satisfaction in the public sector (29).

Our findings showed that full-time geographic specialists had a lower FTE on the whole compared to non-full-time specialists. This finding was true for those engaged in DP as well, however, full-time geographic specialists who did not engage in DP showed a higher FTE. According to the existing (2010) law, full-time specialists are not permitted to work in other sectors (30). Therefore, bearing in mind the direct impact of DP on FTE, it seems rational that non-full-time physicians who engaged more in DP show a higher FTE $(31,32)$. Considering the current law, full-time specialists are obliged to spend at least 1 FTE on medical activities (30). Hence, among non-DP specialists, FTE of full-time specialists was significantly higher than non-full-time specialists, and this is similar to the findings of another study conducted on surgery groups (33). It should be noted that there was no similar study in the Islamic Republic of Iran. Considering limitation of studies from other countries and the relevancy of findings to the Iranian context, we could not clearly delineate previous research in the country from that conducted in other countries. Therefore, this issue was an important limitation of the present study and further discussion in this regard was limited

We found that university faculty surgeons had a higher FTE compared to non-faculty surgeons. Faculty specialists receive more patients since that they have a certain reputation (9), therefore, they spend more time visiting their private patients. However, contrary to our findings, faculty specialists in Brazil spend $32 \%$ less time on medical activities and engage more in educational affairs (34). This could be due to the integration of medical education with health care services in the Islamic Republic of Iran (35), and hence clinical and educational duties of specialists go on simultaneously.

Among specialists who engaged in DP, males had higher FTE than females, while in non-DP specialists the reverse was found. Contradictorily, in a previous study it was found that female surgeons spent more time with their patients than their male peers (36). It is likely that several factors led to this difference among non-DP specialists, but this is not within the scope of the present study.

Among the other factors we studied, age and work experience had an effect on the FTE of surgery groups. Years of surgery experience lead to a tendency among patients to consult highly experienced surgeons (37,38). In the USA, in order to meet regional needs, at least $1.3 \mathrm{FTE}$ is required from each specialist considering the number of consultations with experienced specialists (33). This is because less experienced or young specialists do not have the capacity to compete in other markets or with senior specialists (39) and they allocate their extra time to research or education (40). However, in contrast to the above findings, younger non-DP specialists, especially in less developed areas, had a higher FTE. As indicated in the specialists' rules of service, after graduation, young physicians are recruited to serve as Zarib $\mathrm{K}$ and fulltime specialists in underserved areas (30). Since, there is limited capacity for private activities in these areas, there would be a constraint on the increase of FTE for specialists. Therefore, the young full-time specialists among the non-DP surgeons will have higher FTE.

Although this research was carefully prepared, this study had a number of limitations. First, we encountered a difficulty to access some data, e.g. socioeconomic status of physicians, etc., which could be useful in the analysis of behaviour when engaging in DP. Another limitation was the lack of related literature and studies on level of DP by specialty area, which could facilitate greater accuracy in interpreting our findings. However, we did adopt a variety of approaches for analysis and data collection, which illustrated the level of DP among surgery specialists in the Islamic Republic of Iran.

\section{Conclusion}

On the whole, DP has a direct impact on specialists working hours. A greater share of the difference in working time was expended in the private sector services; consequently this reduced the time spent on the public sector services by dual practitioners compared with non-duals. In practice, the effect was to reduce access to surgeons and quality of services in public health. Particularly, given the high level of out-of-pocket expenditure in the private sector, it led to aggravating the limited access of low-income people and conclusion in long term Uncontrolled DP in the surgery health workforce can have adverse effects on efficiency, effectiveness and quality of services.

Funding: None.

Competing interests: None declared. 


\section{Répercussions de la double pratique sur les délais de prestation de services par les chirurgiens en République islamique d'Iran : analyse pluri-niveau d'une enquête nationale, 2016}

\section{Résumé}

Contexte : L'un des modes de travail qui affecte la disponibilité des médecins spécialistes est le phénomène de la double pratique, c'est-à-dire le cumul de plusieurs activités professionnelles dans les secteurs public et privé. L'absence de contrôle de la double pratique parmi les professionnels de santé en chirurgie peut avoir des répercussions néfastes sur l'accès aux chirurgiens ainsi que sur l'efficacité, la rentabilité et la qualité des prestations chirurgicales.

Objectifs : L'objectif du présent article est d'étudier l'impact de la double pratique sur le temps consacré à la prestation de service par les chirurgiens.

Méthodes : À l'aide d'un formulaire préstructuré, nous avons recueilli des données concernant les chirurgiens spécialisés dans l'ensemble des 925 hôpitaux que compte la République islamique d'Iran. Les données ont été comparées en utilisant les numéros d'identification nationaux des médecins, leurs numéros d'inscription à l'ordre des médecins, leurs prénoms, noms et patronymes. La régression linéaire à plusieurs niveaux a été appliquée afin d'évaluer le lien entre la double pratique et les variables étudiées, à savoir le type de recrutement, l'exercice de fonctions d'enseignement, l'expérience, le sexe et l'âge.

Résultats : Les 4642 chirurgiens spécialisés inclus dans cette étude, représentant 31,08 \% du nombre total des chirurgiens identifiés, consacraient en moyenne 1,09 heure (écart-type :0,33) en équivalent temps plein (ETP) à la prestation de services de soins de santé. Les spécialistes s'adonnant à la double pratique faisaient preuve de temps de prestation plus longs $(\beta$ $=0,427)$. Les femmes spécialistes $(\beta=-0,049)$ et les spécialistes travaillant à temps plein $(\beta=-0,082)$ montraient des temps de prestation plus courts. Les spécialistes permanents avaient un nombre d'ETP plus élevé ( $p<0,001)$, ce dernier croissant avec l'augmentation de la population $(p<0,05)$

Conclusion : Bien que la double pratique ait des répercussions directes sur les horaires de travail des chirurgiens, il semble qu'une plus grande partie de la différence dans le temps de travail soit consacrée à la prestation de services dans le secteur privé, ce qui affecte l'accès aux services chirurgicaux dans le secteur public. Il est donc nécessaire d'élaborer une approche systémique afin de réglementer la double pratique.

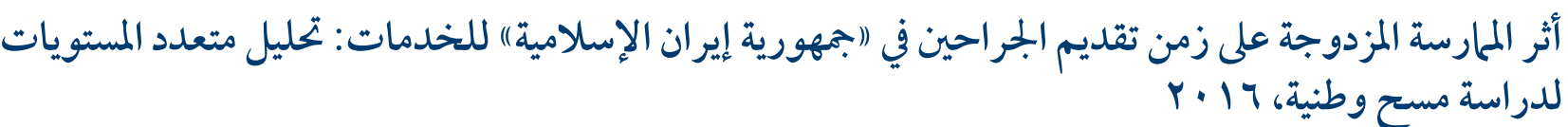

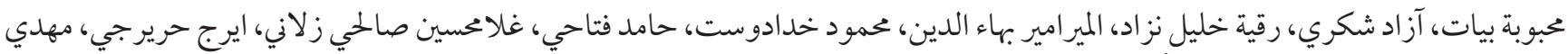

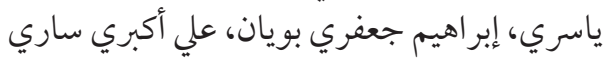

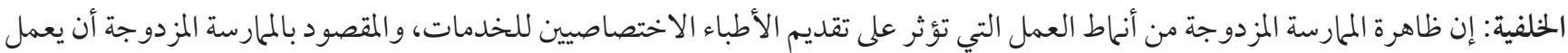

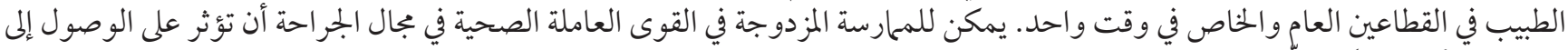

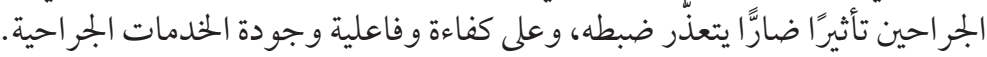

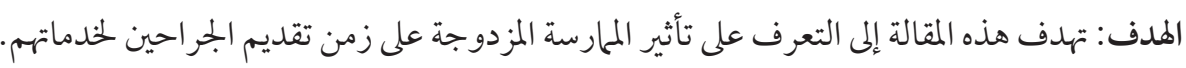

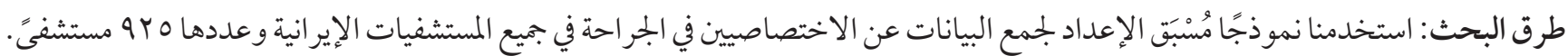

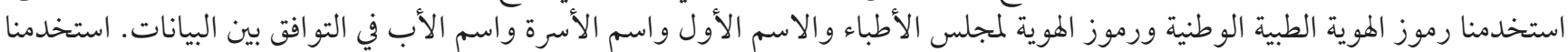

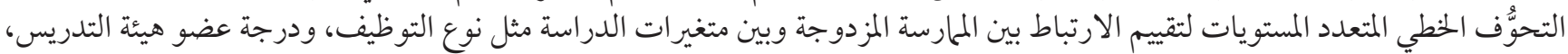
والخبرة، ونوع الجنس النس، و السن.

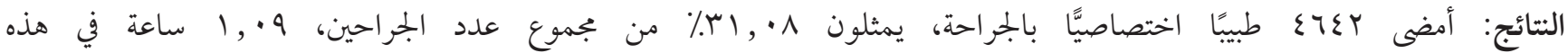

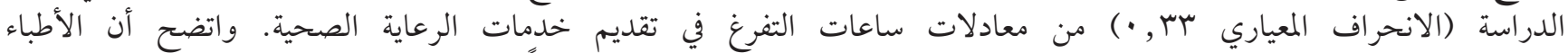

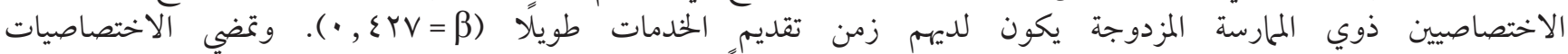

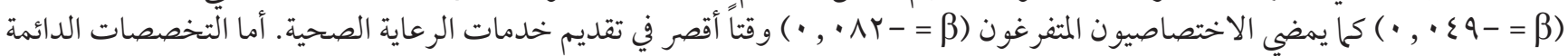

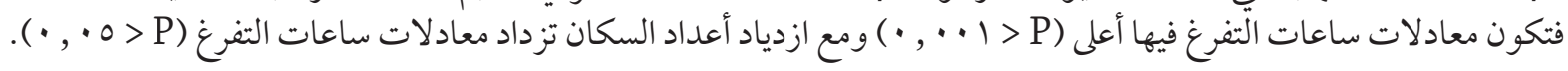

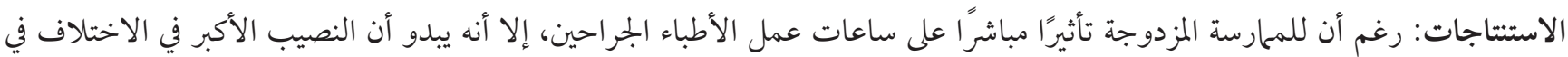

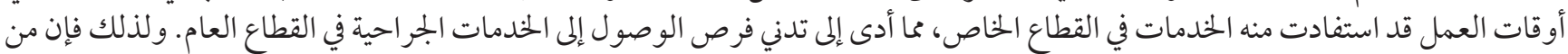

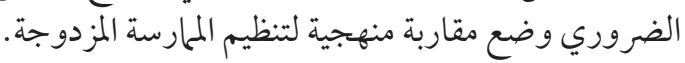




\section{References}

1. Bickler SW, Spiegel DA. Global surgery-defining a research agenda. Lancet. 2008 Jul 12;372(9633):90-2. https://doi.org/10.1016/ So140-6736(08)60924-1 PMID:18582930

2. Shrime MG, Bickler SW, Alkire BC, Mock C. Global burden of surgical disease: an estimation from the provider perspective. Lancet Glob Health. 2015 Apr 27;3 Suppl 2:S8-9. https://doi.org/10.1016/S2214-109X(14)70384-5 PMID:25926322

3. Alkire BC, Shrime MG, Dare AJ, Vincent JR, Meara JG. Global economic consequences of selected surgical diseases: a modelling study. Lancet Glob Health. 2015 Apr 27;3 Suppl 2:S21-7. https://doi.org/10.1016/S2214-109X(15)70088-4 PMID:25926317

4. Alkire BC, Raykar NP, Shrime MG, Weiser TG, Bickler SW, Rose JA, et al. Global access to surgical care: a modelling study. Lancet Glob Health. 2015 Jun;3(6):e316-23. https://doi.org/10.1016/S2214-109X(15)70115-4 PMID:25926087

5. Lantz A, Holmer H, Finlayson S, Ricketts TC, Watters D, Gruen R, et al. International migration of surgeons, anaesthesiologists, and obstetricians. Lancet Glob Health. 2015 Apr 27;3 Suppl 2:S11-2. https://doi.org/10.1016/S2214-109X(15)70084-7 PMID:25926314

6. Abdul Rahim R, Mwanri L. Health workforce crisis: recruitment and retention of skilled health workers in the public health sector in Malaysia. Asia Pacific Journal of Public Administration. 2012;34(2):157-70. https://doi.org/10.1080/23276665.2012.10779392

7. García-Prado A, González P. Policy and regulatory responses to dual practice in the health sector. Health Policy. 2007 Dec;84(23):142-52. https://doi.org/10.1016/j.healthpol.2007.03.006 PMID:17449134

8. Ferrinho P, Van Lerberghe W, Fronteira I, Hipólito F, Biscaia A. Dual practice in the health sector: review of the evidence. Hum Resour Health. 200410 27;2(1):14. https://doi.org/10.1186/1478-4491-2-14 PMID:15509305

9. Johannessen K-A, Hagen TP. Physicians' engagement in dual practices and the effects on labor supply in public hospitals: results from a register-based study. BMC Health Serv Res. 2014 07 10;14(1):299. https://doi.org/10.1186/1472-6963-14-299 PMID:25011448

10. Eggleston K, Bir A. Physician dual practice. Health Policy. 2006 Oct;78(2-3):157-66. https://doi.org/10.1016/j.healthpol.2005.09.007 PMID:16253383

11. Jan S, Bian Y, Jumpa M, Meng Q, Nyazema N, Prakongsai P, et al. Dual job holding by public sector health professionals in highly resource-constrained settings: problem or solution? Bull World Health Organ. 2005 Oct;83(10):771-6. PMID:16283054

12. Ensor T, Duran-Moreno A. Corruption as a challenge to effective regulation in the health sector. In: Saltman R, Busse R, Mossialos E, eds. Regulating entrepreneurial behaviour in European health care systems. Maidenhead: Open University Press; $2002: 106$.

13. Joyce CM, McNeil JJ, Stoelwinder JU. More doctors, but not enough: Australian medical workforce supply 2001-2012. Med J Aust. 2006 May 1;184(9):441-6. PMID:16646743

14. Armstrong BK, Gillespie JA, Leeder SR, Rubin GL, Russell LM. Challenges in health and health care for Australia. Med J Aust. 2007 Nov 5;187(9):485-9. PMID:17979607

15. O'Brien-Pallas L, Baumann A, Donner G, Murphy GT, Lochhaas-Gerlach J, Luba M. Forecasting models for human resources in health care. J Adv Nurs. 2001 Jan;33(1):120-9. https://doi.org/10.1046/j.1365-2648.2001.01645.x PMID:11155116

16. Rogers B, Lawrie L, Reilly C. Doctor statistics in Scandinavia. Denmark, Finland, Norway, Sweden December 2007. Lansdale, Pennsylvania: EphMRA and PBIRG, 2007:18-41 (https://www.pdffiller.com/jsfiller-desk5/?projectId=187034835\&expId=3395\&expBranch=1\#4911fo6oof8a413296cf808bd383b56c, accessed 20 May 2018).

17. Song J, Wang D-l, Bao Y-b, YU G. Study on a metadata-driven ETL approach. MINIMICRO SYSTEMS-SHENYANG-. J Chinese Computer Systems. 2007;28(12):2167.

18. Christen P. Data matching: concepts and techniques for record linkage, entity resolution, and duplicate detection. Berlin: Springer Science \& Business Media; 2012. https://doi.org/10.1007/978-3-642-31164-2

19. A practical guide to FTE calculation. Wellington, New Zealand: TAS; 2012.

20. R Core Team. R: a language and environment for statistical computing. Vienna, Austria: R Foundation for Statistical Computing; 2013.

21. Health workforce 2025: medical specialties, Vol 3. Adelaide: Health Workforce Australia; 2012 (https://submissions.education.gov. au/forms/archive/2015_16_sol/documents/Attachments/Royal\%20Australasian\%20College\%20of\%20Surgeons.pdf, accessed 15 April 2018).

22. National Center for Health Workforce Analysis. Projecting the supply of non-primary care specialty and subspecialty clinicians: 2010-2025. Rockville, Maryland: Health Resources and Services Administration; 2014 (https://bhw.hrsa.gov/sites/default/files/ bhw/nchwa/projections/clinicalspecialties.pdf, accessed 1 May 2018).

23. Stain SC, Hoyt DB, Hunter JG, Joyce G, Hiatt JR. American surgery and the affordable care act. JAMA Surg. 2014 Sep;149(9):984-5. https://doi.org/10.1001/jamasurg.2014.1343 PMID:25103573

24. Badley EM, Canizares M, MacKay C, Mahomed NN, Davis AM. Surgery or consultation: a population-based cohort study of use of orthopaedic surgeon services. PLoS One. 201306 4;8(6):e6556o. https://doi.org/10.1371/journal.pone.0065560 PMID:23750266

25. Chue P. Incentives to dual practice new institutional economic analysis of Canada's mixed public-private health sector [thesis]. Tacoma, Washington: University of Puget Sound; 2007.

26. Socha K. Physician dual practice and the public health care provision: extended literature review; COHERE working paper. Odense: Centre of Health Economics Research University of Southern Denmark; 2010 (2010:4; https://econpapers.repec.org/paper/hhssduhec/2010_5foo4.htm, acessed 15 April 2018). 
27. Hipgrave DB, Hort K. Dual practice by doctors working in South and East Asia: a review of its origins, scope and impact, and the options for regulation. Health Policy Plan. 2014 Sep;29(6):703-16. https://doi.org/10.1093/heapol/czt053 PMID:24150504

28. Ashmore J. 'Going private': a qualitative comparison of medical specialists' job satisfaction in the public and private sectors of South Africa. Hum Resour Health. 201301 3;11(1):1. https://doi.org/10.1186/1478-4491-11-1 PMID:23281664

29. Bergman LP. Dual practice in kampala, uganda: a mixed methods study of management and policy [thesis]. Baltimore, Maryland: Johns Hopkins University; 2014.

30. Iranian Employment Law 2010. Tehran: Islamic Parliament of Iran; (http://old.iums.ac.ir/uploads/aeinname_edariestekhdami. pdf, accessed 20 May 2018) [in Farsi].

31. Bloor K, Maynard A, Freemantle N. Variation in activity rates of consultant surgeons and the influence of reward structures in the English NHS. J Health Serv Res Policy. 2004 Apr;9(2):76-84. https://doi.org/10.1258/135581904322987481 PMID:15099454

32. Morris S, Elliott B, Ma A, McConnachie A, Rice N, Skåtun D, et al. Analysis of consultants' NHS and private incomes in England in 2003/4. J R Soc Med. 2008 Jul;101(7):372-8o. https://doi.org/10.1258/jrsm.2008.080004 PMID:18591691

33. Voelker R. Experts say projected surgeon shortage a "looming crisis" for patient care. JAMA. 2009 Oct 14;302(14):1520-1. https:// doi.org/10.1001/jama.2009.1456 PMID:19826016

34. Scheffer MC, Guilloux AGA, Matijasevich A, Massenburg BB, Saluja S, Alonso N. The state of the surgical workforce in Brazil. Surgery. 2017 02;161(2):556-61. https://doi.org/10.1016/j.surg.2016.09.008 PMID:28341282

35. Marandi SA. The integration of medical education and health care services in the IR of Iran and its health impacts. Iranian J Publ Health. 2009;38:4-12.

36. Colletti LM, Mulholland MW, Sonnad SS. Perceived obstacles to career success for women in academic surgery. Arch Surg. 2000 Aug;135(8):972-7. https://doi.org/10.1001/archsurg.135.8.972 PMID:10922261

37. Wibulpolprasert S, Pengpaibon P. Integrated strategies to tackle the inequitable distribution of doctors in Thailand: four decades of experience. Hum Resour Health. 200311 25;1(1):12. https://doi.org/10.1186/1478-4491-1-12 PMID:14641940

38. Sherr K, Mussa A, Chilundo B, Gimbel S, Pfeiffer J, Hagopian A, et al. Brain drain and health workforce distortions in Mozambique. PLoS One. 2012;7(4):e35840. https://doi.org/10.1371/journal.pone.0035840 PMID:22558237

39. González P, Macho-Stadler I. A theoretical approach to dual practice regulations in the health sector. J Health Econ. 2013 Jan;32(1):66-87. https://doi.org/10.1016/j.jhealeco.2012.08.005 PMID:23202256

40. Cheng TC, Joyce CM, Scott A. An empirical analysis of public and private medical practice in Australia. Health Policy. 2013 Jun;111(1):43-51. https://doi.org/10.1016/j.healthpol.2013.03.011 PMID:23602546 